\title{
Swine waste as a source of natural products: A carotenoid antioxidant
}

\author{
Lawrence B. Cahoon ${ }^{1 *}$, Christopher J. Halkides ${ }^{2}$, Bongkeun Song ${ }^{3}$, C. Michael Williams ${ }^{4}$, \\ George R. Dubay ${ }^{5}$, Alexandra Fries ${ }^{6}$, Johanna Farmer ${ }^{7}$, William Fridrich ${ }^{8}$, \\ Charles Brookshire ${ }^{9}$
}

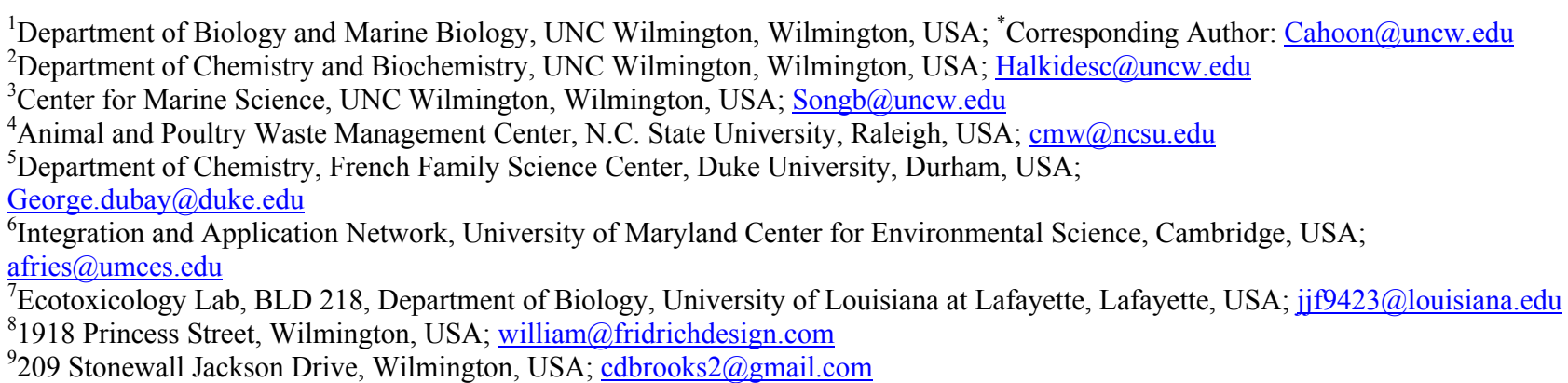

Received 28 June 2012; revised 31 July 2012; accepted 9 August 2012

\begin{abstract}
Development of Environmentally Superior Technologies for swine waste management has focused on extraction of products with relatively low unit values. Analyses of the bacterial composition of swine waste lagoon samples confirmed the presence of several purple non-sulfur bacteria (PNSB) species known to produce a variety of carotenoids. We examined a carotenoid naturally abundant in North Carolina swine waste lagoons dominated by PNSB. Analytical methods including high performance liquid chromatography (HPLC), mass spectrometry, and nuclear magnetic resonance (NMR) confirmed the identity of the dominant carotenoid as spirilloxanthin, $\mathrm{C}_{42} \mathrm{H}_{60} \mathrm{O}_{2}$, with 13 conjugated double bonds. This structure confers antioxidant properties as good as those of carotenoids currently marketed as antioxidants. Visual estimates of the "redness" of swine waste lagoon liquids were highly correlated with carotenoid content. Spirilloxanthin concentrations in a lagoon with a strong PNSB bloom were approximately 0.5 grams $\cdot \mathrm{m}^{-3}$. These results support further investigations into the potential for extracting commercially valuable natural products from swine waste lagoons.
\end{abstract}

Keywords: Swine Waste; Purple Phototrophic Bacteria; Carotenoids; Spirilloxanthin

\section{INTRODUCTION}

Intensive swine production has created several significant environmental challenges, particularly through widespread use of anaerobic waste storage lagoons and land application of lagoon liquids. This waste treatment approach can cause air quality problems with odors [1], gaseous ammonia emissions [2], greenhouse gas emissions (particularly methane), and airborne transport of particulates and aerosols [3], surface water quality problems via lagoon breaches [4], nutrient export from spray fields [5] and downwind wet and dry aerial deposition [6], and groundwater contamination, particularly by excess nitrate [7]. Disputes over these issues in North Carolina led to an agreement among government, industry, and university researchers to seek alternative waste treatment systems, leading to development of several Environmentally Superior Technology (EST) methods [8, 9] and subsequent second generation versions of these methods [10]. Similar challenges are being addressed by researchers elsewhere [11-13].

The primary consideration in development of ESTs is minimization at economically feasible costs of environmental problems associated with conventional waste treatment methods. Most alternative waste treatment systems focus on methods of recovering bulk commodities, e.g., nutrients and bio-solids, or of converting waste into usable sources of energy, directly through methane generation and capture or via biological and chemical transformations into biofuels [14]. Economic benefits to swine producers were also an important consideration; North Carolina's process of EST development has not yet 
created an economically viable alternative to conventional methods. Moreover, the products of these EST systems have relatively low market value, owing partly to low prices for these commodities, geographically concentrated production in excess of local demand, and relatively high costs of transport to export markets. Consequently, in 2007 the North Carolina legislature stipulated use of EST waste treatment systems by new or expanded swine production operations, but left intact the use of conventional lagoon-spray field waste treatment systems by the approximately 2300 existing swine concentrated animal feeding operations (CAFOs) in North Carolina [15]. The problem with North Carolina's approach may have been, as Kronenberg and Winkler [16] argued, a focus on process rather than outcome.

We consider here the potential for utilization of naturally dominant microflora in conventional swine waste lagoons as potential sources of valuable natural products [17]. Swine waste management experts have recognized the importance of microbial assemblages in anaerobic waste treatment, and have provided recommendations for loading rates that support dominance by the purple nonsulfur bacteria (PNSB) that metabolize swine waste constituents particularly well [18-20]. These bacteria are metabolically versatile [21], are capable of photosynthetic and heterotrophic production, use reduced compounds, including many odorants [20,22], as electron donors, and biosynthesize a variety of potentially useful natural products [23]. We focus on one natural product, a carotenoid, from the PNSB that naturally dominate a significant number of swine lagoons in North Carolina, conferring a pink-purple color to them at least seasonally. The pink-purple color of this PNSB assemblage is conferred primarily by carotenoids of the spirilloxanthin and lycopene synthesis series [24,25]. Lycopene is currently marketed as a dietary supplement for its potent antioxidant properties [26]. The primary chromophore of these carotenoids is a long conjugated double bond system (11 - 13 carbon-carbon double bonds), which also confers antioxidant properties of potential commercial interest [27]. We report here the isolation, identification, quantification, and characterization of a carotenoid compound, spirilloxanthin, from swine waste lagoons in southeastern North Carolina.

\section{MATERIALS AND METHODS}

\subsection{Sample Collection}

Swine lagoon samples were obtained in bulk quantities (5 - 10 L) for identification of the dominant carotenoid as needed from a cooperating swine producer in Pender County, NC, whose lagoon was dominated by PNSB year-round. Samples were retrieved in sterile, 1-L screw cap bottles and stored in refrigerators at $4^{\circ} \mathrm{C}$. Experience showed that PNSB concentrations were stable for 1 - 2 months under these conditions, and that the bacteria would float to the top over time, facilitating their removal for analytical work. Lagoon liquid is a complex matrix of bacteria, other organisms, other particulate matter, and numerous dissolved constituents. The dominant purple phototrophic bacteria in the samples analyzed contained substantial amounts of carotenoids, bacteriochlorophylls, and other lipid compounds that required development of extraction and separation techniques suitable for this material. Consequently, identification of the principal carotenoid in waste lagoon liquid employed extraction and liquid chromatographic separation procedures followed by mass spectrometry and nuclear magnetic resonance (NMR) analyses. Additional sets of swine waste lagoon samples were obtained through North Carolina State University's Animal and Poultry Waste Management Center from swine producers and from a cooperating swine integrator company on several occasions as part of their regular quarterly waste sampling and analysis program using sterile 0.5 L bottles. These samples were also refrigerated until sub-samples were withdrawn (after mixing the contents thoroughly) for use in analyses comparing various properties among lagoons.

\subsection{Sample Preparation}

Samples for analysis of total solids concentrations were mixed thoroughly before decanting known volumes, freezing, lyophilizing, and weighing dried solids to \pm 1 mg on a Denver Instruments A-160 electro-balance. Floating material with high contents of purple phototrophic bacteria was decanted from sample bottles, frozen at $-80^{\circ} \mathrm{C}$, and lyophilized using a Virtis Benchtop Freeze Drier. The resulting purple powder was stored at $-4^{\circ} \mathrm{C}$. The initial extraction protocol utilized a modified carotenoid extraction procedure from De Leenheer and Nellis [28], in which 3 - 4 washes of material with a mixture of reagent-grade $\mathrm{KOH}(60 \%)$ and methanol $(\mathrm{MeOH})(1: 10$ ratio by volume) were used to saponify and remove lipids and bacteriochlorophylls. Following centrifugation, the supernatant was decanted and the remaining solid material was washed $2 \times$ with water, then extracted for 2 4 hours in $100 \%$ high performance liquid chromatography (HPLC) grade acetone. This extract was then filtered $(0.2 \mu \mathrm{m})$ and cleaned by solid phase extraction (SPE). The filtered acetone extract was diluted to $\sim 80 \%$ with deionized water, then drawn through a Fisher Sep-Pak reversed phase C18 SPE column that had been conditioned with $100 \%$ acetone and water. Retained carotenoids yielded an orange-red color in the column packing. Following a wash step with $100 \%$ methanol, carotenoids were eluted with a 60:40 mixture of HPLC-grade methyl 
tert-butyl ether (MTBE) and MeOH. These cleaned carotenoid extracts were used immediately in HPLC separations and analyses.

\subsection{Analytical Methods-Carotenoid}

The method of Niedzwiedzki et al. [29] was used with modifications to prepare pigment samples for mass spectral analysis. Cells were mixed with $30 \mathrm{ml}$ of $\mathrm{MeOH} /$ acetone 1:1 and centrifuged in Corex glass tubes at 6000 $\mathrm{g}$ for $5 \mathrm{~min}$ in a Sorvall SS34 rotor. The supernatant containing a mixture of bacteriochlorophyll and carotenoids was collected and dried using a rotary evaporator. The dry residue was dissolved in $\sim 200 \mathrm{ml}$ of $\mathrm{MeOH} /$ petroleum ether (9:1) and saponified using 5\% w/v KOH to decompose the bacteriochlorophyll. The solution was then washed with water in a separatory funnel and the ether layer containing the carotenoids was collected and dried using a stream of nitrogen gas. The final step was chromatography over silica using $85 \%$ hexanes $/ 15 \%$ acetone as the isocratic mobile phase. The sample eluted in bands of distinct colors, with the first fraction being dark orange. This fraction was stored at $-80^{\circ} \mathrm{C}$ under $\mathrm{N}_{2}$ for subsequent mass spectral analysis. Alternately, the method of Komori et al. [30] was used with modifications for mass spectral sample preparation. The bulk of the bacteriochlorophyll was removed by a single extraction with $\sim 200 \mathrm{ml} \mathrm{MeOH}$. Dehydrated pellets were extracted $3 \mathrm{X}$ with $200 \mathrm{ml}$ acetone. N-hexane (1 volume) and water ( 1 volume) were added to the pooled acetone extract ( 1 volume) to transfer the pigments to the $n$ hexane layer. The $n$-hexane fraction was dried in vacuo. The final step was chromatography over silica, as above.

Samples for NMR analyses were prepared according to [28] with modifications. Liquid waste was sampled from the lagoon and placed in volumetric flasks for several days. The pinkish material that floated to the top was lyophilized. In a typical procedure about $1 \mathrm{~g}$ of the lyophilized powder was treated with $60 \% \mathrm{KOH}$ for two hours in the dark with occasional swirling. The solution was diluted six-fold with water and then centrifuged at $16,000-17,000 \mathrm{rpm}$ in a Beckman JA-20 rotor for 45 60 minutes at about $10^{\circ} \mathrm{C}$. The supernatant was discarded and the jelly-like pellet was extracted with $10 \mathrm{ml}$ of phenol using a tissue homogenizer. The phenol solution was extracted using a 50/50 mixture of dichloromethane and cyclohexane as the organic phase and $10 \% \mathrm{KOH} / 5 \%$ $\mathrm{NaCl}$ as the aqueous phase. If an emulsion formed it was broken by filtration using celite. The organic layer was dried with $\mathrm{MgSO}_{4}$ and the solvent was removed by rotary evaporation. The solid was taken up in approximately $25 \mathrm{ml}$ of hexane and $10 \mathrm{ml}$ of $\mathrm{MeOH}$ and transferred to a separatory funnel and shaken. The methanol layer was extracted twice more with portions of hexane.
The combined hexane layers were extracted with a fresh portion of $\mathrm{MeOH}$, and the second portion of $\mathrm{MeOH}$ was extracted with 2 - 3 portions of hexane. Hexane was removed with rotary evaporation.

The final purification step was reversed phase HPLC (RP-HPLC) using a Hewlett Packard HP 1100 system with photo-diode array UV-Vis detection, column temperature set at $25^{\circ} \mathrm{C}$, and a semi-preparatory C-30 column (NEST group; a Maccel $150 \times 10.4 \mathrm{~mm}$ 200-5-C30 column, $5 \mu \mathrm{m}$ particle size and $200 \AA$ pore size). The mobile phase was $60 \% \mathrm{MTBE}$ and $40 \% \mathrm{MeOH}$, and the flow rate was $5 \mathrm{ml}$ per minute. The MTBE had been treated with alumina to remove peroxides then decanted and filtered as usual. The solid was dissolved in the mobile phase plus $10 \% \mathrm{CH}_{2} \mathrm{Cl}_{2}$, passed through a syringe filter, and loaded onto a $2.0 \mathrm{ml}$ sample loop. Compounds were detected by monitoring at 210, 495, and $700 \mathrm{~nm}$ using diode array detection. The last compound to elute was the carotenoid of interest, although at least four other carotenoids were present in smaller amounts. The volume of the combined fractions was noted, and the absorbance spectrum $(300-700 \mathrm{~nm})$ was taken to estimate the amount of carotenoid. The column was periodically cleaned using a gradient of $\mathrm{MeOH}$ and chloroform, with an additional cleaning step using hexane also performed in some instances. Smaller samples were typically purified using a $150 \times 4.6 \mathrm{~mm}$ column of the same stationary phase at a flow rate of $1.0 \mathrm{ml} / \mathrm{min}$.

Sample fractions corresponding to the dominant carotenoid peak fraction were analyzed by mass spectrometry and NMR. High resolution mass spectrometers were used in analyses of separate carotenoid fraction samples: an Applied Biosystems Q-trap 2000 LC-MS system at UNC Wilmington's Center for Marine Science, and a JEOL JMS-SX102A HRMS system and an Agilent 6224 LCMS-TOF system with an Agilent series 1200 LC at the Department of Chemistry at Duke University. NMR data were acquired on a Varian Inova $800 \mathrm{MHz}$ NMR equipped with a cryoprobe at the Duke Magnetic Resonance Spectroscopy Center. Standard $1 \mathrm{D}{ }^{1} \mathrm{H},{ }^{1} \mathrm{H} /{ }^{1} \mathrm{H}$ COSY (correlated spectroscopy), ${ }^{1} \mathrm{H} /{ }^{1} \mathrm{H}$ TOCSY (total correlation spectroscopy), ${ }^{1} \mathrm{H} /{ }^{13} \mathrm{C}$ HSQC (heteronuclear single quantum coherence), and ${ }^{1} \mathrm{H} /{ }^{13} \mathrm{C}$ HMBC (heteronuclear multiple bond coherence) spectra were obtained at room temperature in $99.96 \% \mathrm{CDCl}_{3}$ (Cambridge Isotope Laboratories, Andover, MA). The program WINDNMR-pro (Hans J. Reich) was used for spectral simulations.

\subsection{Comparisons among Lagoon Samples}

Properties of samples from a variety of swine waste lagoons analyzed and reported include total carotenoid and bacteriochlorophyll contents and visible color spec- 
trum. Total carotenoid content in swine waste samples was measured as absorbance at $495 \mathrm{~nm}$ in acetone extracts of materials filtered onto Gelman $\mathrm{A} / \mathrm{E}$ glass fiber filters. Typical filtered volumes were 2 - $4 \mathrm{ml} / \mathrm{sample}$. Bacteriochlorophyll content was measured as absorbance at $780 \mathrm{~nm}$ for the same extracted samples.

The visible color of swine waste lagoon samples was analyzed using a digital (2 MB) photograph of each waste lagoon sample in a clear polystyrene Petri plate. Each of the images (124 total) was produced identically in focus, size and resolution with a custom camera mount, and included a white/gray/black color target to allow exact color temperature matching among the individual photographs. Each image was sampled and ordinated according to its measured hue value (most red to least red) expressed in degrees $\left(0^{\circ}-360^{\circ}\right)$ in the standard HSV (Hue, Saturation, and Value or Brightness, HSB) color space. The red primary area in the color space was approximately $350^{\circ}$ to $10^{\circ}$. The color study representation may be seen here: http://gallery.me.com/williamfridrich\# 100282. For information on HSV see: http://en.wikipedia. org/wiki/HSL color_space.

\subsection{Antioxidant Capacity Analyses}

The anti-oxidant properties of the principal carotenoid isolated from swine lagoon waste were further analyzed using two different published assays for lipophilic antioxidants [31,32]. Purified fractions of swine waste carotenoid were prepared by HPLC using a semi-preparatory C30 column and isocratic 60:40 MTBE:MeOH elution as above. These purified fractions were assayed using the ABTS procedure of Re et al. [31] and the DPPH method of Brand-Williams et al. [32] with some modifications. ABTS (2,2'-azinobis(3-ethylbenzothiazoline-6-sulfonic acid) diammonium salt; Sigma) was dissolved in water to $7 \mathrm{mM}$ concentration (5 tablets of ABTS as supplied dissolved in $13 \mathrm{ml}$ DI water). Potassium persulfate solution (2.4 ml@ $2.45 \mathrm{mM}$ ) was mixed with ABTS solution and allowed to react for $24 \mathrm{~h}$ in the dark to form a stable, highly colored free radical solution. To prepare the final ABTS solution for the assay, $1 \mathrm{ml}$ of ABTS was diluted with $19 \mathrm{ml}$ ethanol to obtain an absorbance of approximately 0.70 at $734 \mathrm{~nm}$. For each reaction $150 \mu \mathrm{l}$ of standard carotenoid (lycopene and beta-carotene) or swine waste carotenoid solution was added to $2.85 \mathrm{ml}$ of the final ABTS solution. The absorbance at $734 \mathrm{~nm}$ was taken using a spectrophotometer each minute for $6 \mathrm{~min}$. The absorbance values decreased for the duration of the reaction due to reduction of the ABTS pre-formed radical cation by hydrogen donation of the antioxidant compound in question. As ABTS is a decolorization assay, the degree of color reduction during the reaction corresponded with the antioxidant power of the carotenoid.
Molar concentrations of respective carotenoids were determined by published values for molar absorptivities in known solvents [33]. Decolorization was expressed as change in absorbance nmol ${ }^{-1}$ of carotenoid, with higher values corresponding to greater antioxidant capacity. DPPH (2,2-diphenyl-1-picrylhydrazyl) is another stable, highly colored free radical in solution. A stock solution was prepared by dissolving $24 \mathrm{mg}$ DPPH in $100 \mathrm{ml}$ $\mathrm{MeOH}$ and stored at $-10^{\circ} \mathrm{C}$. The working solution was acquired by adding $10 \mathrm{ml}$ of stock solution to $45 \mathrm{ml}$ $\mathrm{MeOH}$ to obtain an absorbance reading of approximately 1.1 at $515 \mathrm{~nm}$. For each reaction $150 \mu \mathrm{l}$ of standard carotenoid or swine waste carotenoid was added to $2.85 \mathrm{ml}$ of the DPPH solution and allowed to react for $24 \mathrm{~h}$ in the dark. Absorbance readings were then measured at 515 nm. Subsequent to the reaction, the absorbance values decreased due to the reduction of the DPPH free radical by the donation of hydrogen ions from the carotenoid. Molar concentrations of respective carotenoids were determined as above, and antioxidant capacity of each carotenoid was expressed as change in absorbance $\mathrm{nmol}^{-1}$.

\subsection{Bacterial Community Composition}

Bacterial composition in a lagoon slurry was determined with triplicate samples collected from the Pender County lagoon. A serial dilution from 1:1 to 1:1000 was made from the swine lagoon slurry and $50 \mu \mathrm{l}$ of each dilution was spread onto R2A agar plates in duplicate. The plates were placed in a $30^{\circ} \mathrm{C}$ incubator and allowed to grow for 3 days. Isolates that resulted in pigment formation were transferred to fresh R2A plates and incubated for $24 \mathrm{~h}$. Genomic DNA from the hog lagoon isolates was extracted using the Gentra ${ }^{\circledR}$ Puregene $^{\circledR}$ DNA Purification Kit (Gentra Systems, Inc.; Minneapolis, $\mathrm{MN}$ ). 16S rRNA genes were amplified using 27F and 685R primers [34] and Promega GoTaq ${ }^{\circledR}$ Master Mix (Promega Corporation; Madison, WI) according to manufacturer's protocol with a $55^{\circ} \mathrm{C}$ primer annealing in a $50 \mu 1$ reaction volume. Polymerase chain reaction (PCR) amplicons with the 1542 base pair (bp) size were determined by agarose gel electrophoresis (1\% (wt/vol)) and were purified using the Promega Wizard ${ }^{\circledR}$ SV Gel and PCR Clean-Up System (Promega Corporation; Madison, $\mathrm{WI})$. The purified products were sequenced using the ABI Prism ${ }^{\circledR} 3100$ Genetic Analyzer (Applied Biosystems; Foster City, CA). The sequences obtained were BLASTsearched (http://www.ncbi.nih.gov/) to determine the closest matched bacterial species.

\section{RESULTS}

\subsection{Bacterial Community Composition}

Bacterial isolates from the swine lagoon samples were 
selected based on the differences in colony colors and shapes. Fifty three isolates were obtained and identified using 16S rRNA gene sequences (Table 1). Twenty two isolates produced visible pigments based on the growth on R2A plates. Among them, 7 isolates generating red pigments belong to the genera of Rhodococcus, Rhodobacter, Pseudomonas, or Thermomonas (Table 1), which include species capable of synthesizing spirilloxanthin [24].

Table 1. Bacterial isolates from swine waste lagoons and taxonomic identification based on 16S rRNA gene sequences.

\begin{tabular}{|c|c|c|}
\hline Bacterial Isolate & Colony Color & Bacterial Identification \\
\hline HL1/HL7/HL9 & Red & Thermomonas sp. \\
\hline HL 10 & White & Nocardiopsis sp. \\
\hline HL11 & White & Bacillus sp. \\
\hline HL 13 & Orange & Deinococcus sp. \\
\hline HL14/HL41 & Cream & Pseudomonas sp. \\
\hline HL15/HL28/HL45 & White & Acinetobacter sp. \\
\hline HL16 & Cream & Psychrobacter sp. \\
\hline HL17/HL39/HL43 & Yellow & Flavobacterium sp. \\
\hline HL19 & Cream & Proteus sp. \\
\hline HL2/HL18 & Yellow & Sphingobacterium sp. \\
\hline HL20 & Clear & Corynebacterium sp. \\
\hline HL21 & White & Imtechium sp. \\
\hline \multicolumn{3}{|l|}{ HL22/HL31/HL48/ } \\
\hline HL49/HL50/HL51 & Yellow & Comamonas sp. \\
\hline HL27 & White & Rhizobium sp. \\
\hline HL29 & Yellow & Chryseobacterium sp. \\
\hline HL3/HL4/HL8/HL30 & White & Alcaligenes sp. \\
\hline HL32/HL36/HL53 & Clear & Hydrogenophaga sp. \\
\hline HL33 & Yellow & Arcobacter sp. \\
\hline HL34/HL40/HL42 & Clear & Azonexus sp. \\
\hline HL35 & Clear & Acidovorax sp. \\
\hline HL37 & Red & Rhodobacter sp. \\
\hline HL38 & White & Dechloromonas sp. \\
\hline HL44 & White & Porphyromonadaceae sp. \\
\hline HL46 & Green & Acidovorax sp. \\
\hline HL47 & Red & Pseudomonas sp. \\
\hline HL5/HL6 & Red & Rhodococcus sp. \\
\hline HL52 & Yellow & Kocuria sp. \\
\hline
\end{tabular}

\subsection{Carotenoid Identification}

HPLC separation of swine waste bacterial pigments yielded chromatograms that typically exhibited a rapidly eluted peak identified by its absorbance spectrum as bacteriochlorophyll, followed by a series of peaks with absorbance spectra consistent with carotenoids. The last eluting and usually largest peak had an absorbance spectrum in HPLC eluent that closely matched literature values for spirilloxanthin (Figure 1, Table 2).

Mass spectrometry of an HPLC eluent fraction corresponding to the largest HPLC peak using the Applied Biosystems Q-trap 2000 LC-MS system yielded peaks with mass estimates of 596.8 and 597.7 amu and tentative molecular formula of $\mathrm{C}_{42} \mathrm{H}_{60} \mathrm{O}_{2}$, both consistent with published values for spirilloxanthin [36]. DART-MS spectra obtained from a carotenoid fraction that had been purified over silica yielded an exact mass of 596.4585 $\mathrm{amu}$, which is $0.5 \mathrm{ppm}$ from the calculated mass $596.4588 \mathrm{amu}$ for $\mathrm{C}_{42} \mathrm{H}_{60} \mathrm{O}_{2}$. The result using $\mathrm{EI}$ on the JEOL SX-102 was also within the 5.0 ppm criterion for accurate mass confirmation. These results are consistent with spirilloxanthin. Two other carotenoids were also observed, with masses of 490.3807 and $613.4617 \mathrm{amu}$, but were not further characterized.

Initial ${ }^{1} \mathrm{H}$ NMR assignments were made on the basis of coupling constants. Initial ${ }^{13} \mathrm{C}$ NMR assignments were made on the basis of HSQC data. COSY and HMBC spectra were used to resolve ambiguities, and the latter spectrum was also used to assign quaternary carbon atoms. H-14 was assigned on the basis of spectral simulations of AA'XX' systems, with the parameters $\mathrm{J}_{\mathrm{XX}} \mathrm{X}^{\prime}=15$ $\mathrm{Hz}, \mathrm{J}_{\mathrm{AX}}=11.2 \mathrm{~Hz}$, and $\mathrm{J}_{\mathrm{AX}}=-3 \mathrm{~Hz}$ reproducing the main features of the relevant portion of the spectrum. The ${ }^{3} \mathrm{~J}_{\mathrm{HH}}$ coupling constants are $\mathrm{J}_{2,3}=7.6 \mathrm{~Hz}, \mathrm{~J}_{3,4}=15.6$ $\mathrm{Hz}, \mathrm{J}_{6,7}=11.3 \mathrm{~Hz}, \mathrm{~J}_{7,8}=14.9 \mathrm{~Hz}, \mathrm{~J}_{10,11}=11.4 \mathrm{~Hz}$, and

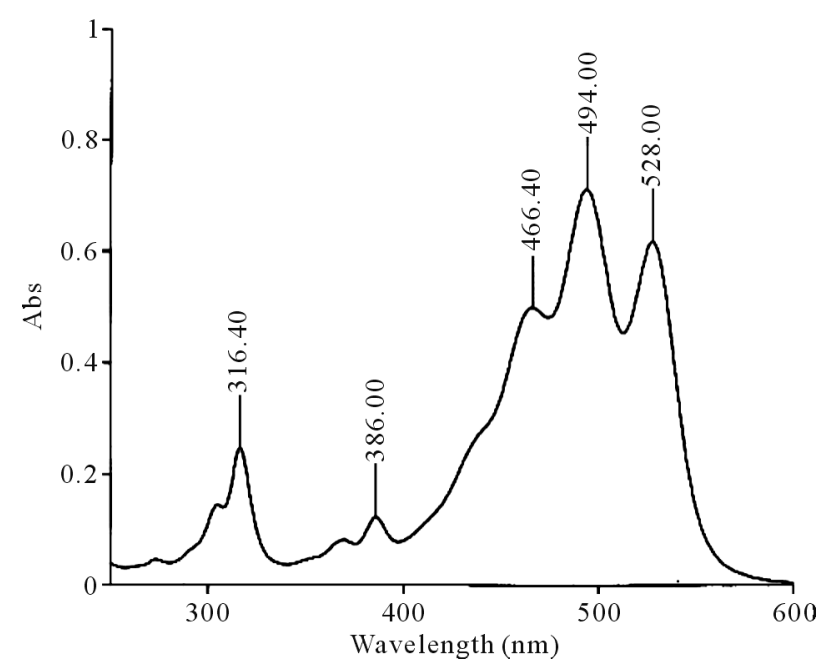

Figure 1. Absorption spectrum of purified carotenoid in 60:40 MTBE:MeOH HPLC eluent. 
Table 2. Absorbance spectra (maxima, nm) of HPLC candidate peak in Figure 1 vs published values for spirilloxanthin [35].

\begin{tabular}{ccccccc}
\hline Solvent system & pk 1 & pk 2 & pk I & pk II & pkIII & III/II \\
\hline Published values & & & & & & \\
Methanol & 315 & 385 & 464 & 492 & 524 & $64 \%$ \\
"HPLC eluent" & & & 469 & 498 & 531 & $64 \%$ \\
n-hexane (all trans) & 365 & 386 & 463 & 492 & 526 & \\
n-hexane (13-cis) & 368 & 386 & 460 & 488 & 520 & \\
n-hexane (15-cis) & 367 & 385 & 462 & 490 & 524 & \\
This study & & & & & & \\
60:40 MTBE:MeOH & 316.4 & 386 & 466.4 & 494 & 528 & $62 \%$ \\
\hline
\end{tabular}

$\mathrm{J}_{11,12}=14.8 \mathrm{~Hz}$. The ${ }^{1} \mathrm{H}$ NMR [37] and ${ }^{1} \mathrm{H}$ and ${ }^{13} \mathrm{C}$ [38] assignments of all trans-spirilloxanthin have been reported. The chemical shifts (Table 3) and coupling constants of our main carotenoid were in close agreement with these previous reports. A small number of nuclei could not be assigned independently of the previous assignments. The chemical shifts and coupling constants we observed support the identification of the main carotenoid as being symmetric and in an all-trans configuration. Based on these results, we have identified this carotenoid as spirilloxanthin (1,1'-Dimethoxy-3,4,3',4'-tetradehydro-1,2,1',2'-tetrahydro- $\Psi, \Psi$-carotene; Figure 2). We note that spirilloxanthin can occur in various cistrans isomers, and that it is possible that some of the earlier peaks in our HPLC chromatograms were spirilloxanthin isomers, as their absorbance spectra in HPLC eluent were very similar.

\subsection{Antioxidant Capacity}

Antioxidant capacity analyses of the HPLC fraction identified as spirilloxanthin yielded estimates comparable to lycopene and greater than or equal to $\beta$-carotene in paired comparisons (Table 4). Analysis of variance of results from ABTS assays revealed no significant differences among the three carotenoids $(\mathrm{F}=0.44, \mathrm{df}=2.37, \mathrm{p}$ $=0.65)$. Analysis of variance and Tukey-Kramer $a$ posteriori tests for DPPH assays revealed that spirilloxanthin had antioxidant capacity higher than $\beta$-carotene and capacity equal to that of lycopene $(\mathrm{F}=7.11, \mathrm{df}=2.37, \mathrm{p}=$ $0.0024, \alpha=0.05$ ). Thus, spirilloxanthin had equivalent if not greater antioxidant capacity than two carotenoid preparations currently marketed as antioxidants.

\subsection{Carotenoid Concentration}

The approximate spirilloxanthin concentration in the swine waste lagoon sampled in Pender County was estimated by a combination of methods. Replicate $(4 \times) 45$

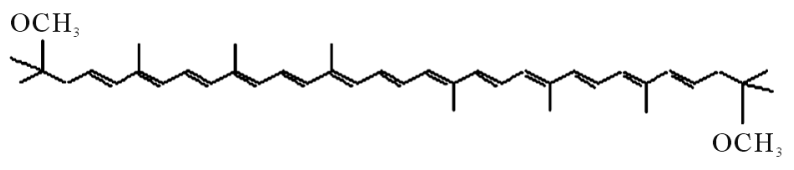

Figure 2. Spirilloxanthin chemical structure; note 13 conjugated double bonds.

Table 3. NMR chemical shifts of putative spirilloxanthin.

\begin{tabular}{|c|c|c|}
\hline Name & C-13 chemical shift, ppm & H-1 chemical shift, ppm \\
\hline HCO- & 49 & 3.23 \\
\hline $\mathrm{C}-1$ & 74.5 & \\
\hline $\mathrm{C}-2$ & 43.9 & 2.32 \\
\hline $\mathrm{C}-3$ & 125 & 5.72 \\
\hline C-4 & 137.4 & 6.16 \\
\hline C-5 & 135.2 & \\
\hline C- 6 & 130.6 & 6.11 \\
\hline $\mathrm{C}-7$ & 124.8 & 6.60 \\
\hline $\mathrm{C}-8$ & 137.4 & 6.35 \\
\hline C-9 & $?$ & \\
\hline $\mathrm{C}-10$ & 132.4 & 6.23 \\
\hline $\mathrm{C}-11$ & 124.9 & 6.65 \\
\hline $\mathrm{C}-12$ & 137.2 & 6.38 \\
\hline $\mathrm{C}-13$ & $?$ & \\
\hline C-14 & 132.6 & 6.27 \\
\hline $\mathrm{C}-15$ & 130.2 & 6.65 \\
\hline C-16, C-17 & 24.1 & 1.16 \\
\hline $\mathrm{C}-18$ & 13 & 1.93 \\
\hline C-19 & 12.9 & 1.98 \\
\hline $\mathrm{C}-20$ & 12.9 & 1.98 \\
\hline
\end{tabular}

Table 4. Results of antioxidant capacity tests of lycopene, $\beta$ carotene, and spirilloxanthin using ABTS and DPPH assays.

\begin{tabular}{|c|c|c|c|}
\hline ABTS & & & \\
\hline Carotenoid & Lycopene & $\beta$-carotene & Spirilloxanthin \\
\hline$\Delta$ Absorbance $\mathrm{nmol}^{-1}$ & 0.932 & 1.155 & 1.024 \\
\hline $\mathrm{n}$ & 10 & 10 & 20 \\
\hline s.e. & 0.168 & 0.168 & 0.119 \\
\hline \multicolumn{4}{|l|}{ DPPH } \\
\hline Carotenoid & Lycopene & $\beta$-carotene & Spirilloxanthin \\
\hline$\Delta$ Absorbance $\mathrm{nmol}^{-1}$ & 0.051 & 0.039 & 0.066 \\
\hline $\mathrm{n}$ & 10 & 10 & 20 \\
\hline s.e. & 0.0058 & 0.0058 & 0.0041 \\
\hline
\end{tabular}


$\mathrm{ml}$ aliquots of fresh swine waste frozen, freeze-dried, saponified with methanolic $\mathrm{KOH}$ as in Section 2.3 to remove lipids and bacteriochlorophyll, then extracted overnight in $10 \mathrm{ml}$ of 80:20 acetone/MeOH. Absorbance of centrifuged extracts at $496 \mathrm{~nm}$ was measured in glass $1 \mathrm{~cm}$ cuvets and the concentration of spirilloxanthin was calculated using the formula: concentration $(\mathrm{M})=\mathrm{ab}-$ sorbance/(molar absorptivity $\times$ path length) using a molar absorptivity value of $147,000 \mathrm{AU} \mathrm{mol}^{-1} \mathrm{~L} \mathrm{~cm}^{-1}$ at 496 $\mathrm{nm}$ for spirilloxanthin [39]. Spirilloxanthin represented about $35 \%$ of total peak area at $495 \mathrm{~nm}$ for chromatograms of swine waste samples, so the calculated concentration was corrected thereby, yielding an average of $0.98 \mu \mathrm{M}$ spirilloxanthin, or an average of about 0.58 $\mathrm{g} \cdot \mathrm{m}^{-3}$ spirilloxanthin (at $596.458 \mathrm{~g} \cdot \mathrm{mol}^{-1}$ ) in raw waste. Total solids concentrations from this swine waste lagoon were in the range of $\sim 5 \mathrm{~kg} \cdot \mathrm{m}^{-3}$, so spirilloxanthin content was on the order of $0.01 \%$ of total solids by weight. The presence of other carotenoids could yield total carotenoid concentrations 2 - 3 times these levels.

Regression analysis compared color wheel scores (expressed as degrees on a 0 - 360 scale) to carotenoid concentrations measured as absorbance@495 nm of acetone extracts of filtered lagoon samples. This analysis revealed a highly significant relationship, $\mathrm{F}=129.8 \mathrm{df}=$ $1.90, \mathrm{p}<0.0001, \mathrm{R}_{\mathrm{Adj}}^{2}=0.59$, indicating that a visual assessment of the "redness" of lagoon color reliably corresponded to actual carotenoid content. Lagoons without significant PNSB blooms frequently appeared dark brown or pale green.

\section{DISCUSSION}

Swine producers have known for decades that many waste lagoons designed and maintained with certain waste loading rates will develop PNSB blooms that help in odor suppression. Odor management recommendations have specifically recognized the importance of waste loading rates and bacterial processes [18]. Consequently, USDA Natural Resource Conservation Service (NRCS) guidelines for swine waste lagoon establishment call for a lagoon liquid volume equivalent to at least approximately 1 cubic $\mathrm{ft}$ per pound of live weight of average-sized animals to be served by that lagoon [40]. Industry experience has shown that this guideline works well for grower-finisher and sow operations but less well for nursery operations, likely owing to differences among swine diets and subsequent waste contents. Using carotenoid concentrations measured chemically and by visual methods as proxies for PNSB biomass, our data show that there was considerable variation in PNSB concentrations in swine lagoons in eastern North Carolina. At the low end of that range were lagoons that were either receiving no or low waste inputs (secondary lagoons in sequenced lagoon systems, pale green color) or that may have been overloaded (dark brown or black colors) and releasing considerably more odor [41] than lagoons with high concentrations of bacteriochlorophyll and carotenoids.

Visual assessments of lagoon color are reasonably accurate predictors of carotenoid content. The heavily colored lagoons whose contents we analyzed likely contained quantities of spirilloxanthin on the order of grams $\mathrm{m}^{-3}$, although we can not rule out that other heavily colored lagoons may also contain other carotenoids, such as lycopene, in addition to various carotenoid precursors of these compounds for total carotenoid concentrations several times higher. Individual operators can thus easily assess the status of their lagoons; broader scale assessments can be obtained by use of aerial surveillance. Google Earth imagery provides informative snapshots of the relative proportions of the color spectrum represented by swine waste lagoons across the broader landscape.

The PNSB include species capable of synthesizing the spirilloxanthin series of carotenoids as well as the lycopene and okenone series, among other carotenoids [42]. We have not identified lycopene or other carotenoids in any samples analyzed for this work, but have not yet analyzed samples from sufficient numbers of swine lagoons to establish predominance by one bacteria/carotenoid type or another, nor have we sampled across sufficient seasons to detect clear temporal variability in carotenoid production patterns.

The antioxidant properties of spirilloxanthin are consistent with its molecular structure: a relatively long backbone of 13 conjugated double bonds and very weakly polar terminal methoxy groups. Two antioxidant capacity assays demonstrated that spirilloxanthin is similar if not superior to lycopene and $\beta$-carotene in this regard, but further antioxidant testing would be necessary for development of spirilloxanthin as an antioxidant product for commercial purposes. Carotenoids currently marketed as antioxidants, including lycopene, $\beta$-carotene, astaxanthin, lutein and zeaxanthin, are all derived from sources in the natural human food chain, whereas spirilloxanthin has to the best of our knowledge never been obtained from human food sources. Consequently, more detailed evaluations of its properties and possible beneficial uses as a nutraceutical would be required before commercialization.

Most proposals for alternate approaches to swine waste management have derived from conventional uses of animal manures as fertilizer supplements and soil amendments, traditional agricultural practices. Current interest in extraction of energy resources from animal wastes may, in a sense, also derive from traditional uses of animal feces as fuel, based on high organic content of most manures. As the Smithfield Agreement process de- 
termined in its final evaluation, however, most such approaches are not economically feasible, as they cost more to implement than the conventional lagoon-spray field waste management system and do not yield products of sufficient value to offset those costs, particularly when transport costs are considered. The geographic concentration of swine waste production, e.g., predominantly in eastern North Carolina, creates a locally saturated market where the value of such products is low, while transport costs to markets at any distance would be considerable.

The results of this research raise the possibility that commercially useful natural products may be obtained from swine waste lagoons, which may be viewed as large bioreactors. The full extent of the natural products that may be available from this source is yet to be determined, as are conditions and lagoon management practices that may support higher production of desirable products while performing waste treatment functions adequately. The full potential of swine waste as a source of microbial compounds thus remains to be explored. Clearly, further research is needed to address these questions.

\section{ACKNOWLEDGEMENTS}

This research was supported by a Research Competitiveness Fund award from the University of North Carolina General Administration, by the North Carolina Pork Council, and by funds provided by UNC Wilmington. We thank the Duke Magnetic Resonance Spectroscopy Center, which is supported by the NSF, the NIH, HHMI, the North Carolina Biotechnology Center, and Duke University. We thank our Pender County collaborator for access to his swine waste lagoon, and Lynn Worley-Davis and cooperating swine producers for additional lagoon samples. We thank Nicholas Wilken and Alexander Amaya for technical assistance.

\section{REFERENCES}

[1] Schiffman, S.S., Bennett, J.L. and Raymer, J.H. (2001) Quantification of odors and odorants from swine operations in North Carolina. Agricultural and Forest Meteorology, 108, 213-240. doi:10.1016/S0168-1923(01)00239-8

[2] Szogi, A.A., Vanotti, M.B. and Stansbery, A.E. (2006). Reduction of ammonia emissions from treated anaerobic swine lagoons. Trans Amer Soc Agri Biol Engin, 49, 217-225.

[3] Harper, L.A., Weaver, K.H., Flesch, T.K., Wilson, J.D., Millner, P.D. and Ingram, D.T. (2005) Nitrogen and other trace-gas emissions from swine production in the central Great Basin. Final Report, USDA Agreement \#586612-3-234, $38 \mathrm{p}$.

[4] Mallin, M.A. and Cahoon, L.B. (2003) Industrialized animal production-A major source of nutrient and microbial pollution to aquatic ecosystems. Population and Environment, 24, 369-385.

doi:10.1023/A:1023690824045
[5] Novak, J.M., Watts, D.W., Hunt, P.G. and Stone, K.C. (2000) Phosphorus movement through a coastal plain soil after a decade of intensive swine manure application. Journal of Environmental Quality, 29, 1310-1315. doi:10.2134/jeq2000.00472425002900040038x

[6] Costanza, J.K., Marcinko, S.E., Goewert, A.E. and Mitchell, C.B. (2008) Potential geographic distribution of atmospheric nitrogen deposition from intensive livestock production in North Carolina, USA. Science of the Total Environment, 398, 76-86.

doi:10.1016/j.scitotenv.2008.02.024

[7] Israel, D.W., Showers, W.J., Fountain, M. and Fountain, J. (2005) Nitrate movement in shallow ground water from swine-lagoon-effluent spray fields managed under current application regulations. Journal of Environmental Quality, 34, 1828-1842. doi:10.2134/jeq2004.0338

[8] Vanotti, M.B., Szogi, A.A., Hunt, P.G., Millner, P.D. and Humenik, F.J. (2007) Development of environmentally superior treatment system to replace anaerobic swine lagoons in the USA. Bioresource Technology, 98, 31843194. doi:10.1016/j.biortech.2009.02.019

[9] Williams, C.M. (2009) Development of environmentally superior technologies in the US and policy. Bioresource Technology, 100, 5512-5518.

doi:10.1016/j.biortech.2009.01.067

[10] Vanotti, M.B., Szogi, A.A., Millner, P.D. and Loughrin, J.H. (2009) Development of a second-generation environmentally superior technology for treatment of swine manure in the USA. Bioresource Technology, 100, 54065416. doi:10.1016/j.biortech.2009.02.019

[11] Bernet, N. and Beline, F. (2009) Challenges and innovations on biological treatment of livestock effluents. Bioresource Technology, 100, 5431-5436. doi:10.1016/j.biortech.2009.02.003

[12] Bortone, G. (2009) Integrated anaerobic/aerobic biological treatment for intensive swine production. Bioresource Technology, 100, 5424-5430. doi:10.1016/j.biortech.2008.12.005

[13] Kunz, A., Miele, M. and Steinmetz, R.L.R. (2009) Advanced swine manure treatment and utilization in Brazil. Bioresource Technology, 100, 5485-5489. doi:10.1016/j.biortech.2008.10.039

[14] Cantrell, K.B., Ducey, T., Ro, K.S. and Hunt, P.G. (2008) Livestock waste-to-energy generation opportunities. Bioresource Technology, 99, 7941-7953. doi:10.1016/j.biortech.2008.02.061

[15] General Assembly of North Carolina, Session 2007 Senate Bill 1465. An act to 1) codify and make permanent the swine farm animal waste management system performance standards that the general assembly enacted in 1998; 2) provide for the replacement of a lagoon that is an imminent hazard; 3) assist farmers to voluntarily convert to innovative animal waste management systems; and 4) establish the swine farm methane capture pilot program. http://www.ncleg.net/Sessions/2007/Bills/Senate/HTML/ S1465v7.html Last accessed 10/28/11

[16] Kronenberg, J. and Winkler, R. (2009) Wasted waste: An evolutionary perspective on industrial by-products. ECO- 
logical Economics, 68, 3026-3033. doi:10.1016/j.ecolecon.2009.07.006

[17] Cahoon, L.B. (2003) Intensive livestock production in North Carolina: Problems, progress and lessons. Proceedings of the Manure Management Conference 2003, Agriculture, Food and Rural Development, Conservation and Development Branch, Edmonton, pp. 1-5

[18] Barker, J.C. (1978) Putting the lid on odor: II. Hog Farm Manage 15 June 1978.

[19] Earle, J.F.K., Koopman, B. and Lincoln, E.P. (1984) Role of purple sulfur bacteria in swine waste reclamation. $\mathrm{Ag}$ ricultural Wastes, 10, 297-312. doi:10.1016/0141-4607(84)90005-2

[20] Kim, M.K., Choi, K.-M., Yin, C.-R., Lee, K.-Y., Im, W.-T., Lim, J.H. and Lee, S.-T. (2004). Odorous swine wastewater treatment by purple non-sulfur bacteria, Rhodopseudomonas palustris, isolated from eutrophicated ponds. Biotechnology Letters, 26, 819-822. doi:10.1023/B:BILE.0000025884.50198.67

[21] Imhoff, J.F. (1995) Taxonomy and physiology of phototrophic purple bacteria and green sulfur bacteria. In: Blankenship, R.E., Madigan, M.T. and Bauer, C.E., Eds., Anoxygenic Photosynthetic Bacteria, Kluwer Academic Publishers, Dordrecht, 1-15.

[22] Do, Y., Schmidt, T., Zahn, J., Boyd, E., de la Mora, A. and Dispirito, A. (2003) Role of Rhodobacter sp. strain PS9, a purple non-sulfur photosynthetic bacterium isolated from an anaerobic swine waste lagoon, in odor remediation. Applied and Environmental Microbiology, 69, 1710-1720. doi:10.1128/AEM.69.3.1710-1720.2003

[23] Sasaki, K., Watanabe, M., Suda, Y., Ishizuka, A. and Noparatnaraporn, N. (2005) Applications of photosynthetic bacteria for medical fields. Journal of Bioscience and Bioengineering, 100, 481-488. doi:10.1263/jbb.100.481

[24] Holt, J.G., Krieg, N.R., Sneath, P.H., Staley, J.T. and Williams, S.T. (2003) Group 10 anoxygenic phototrophic bacteria. In: Williams, H.R., Ed., Bergey's Manual of Determinative Bacteriology, Williams and Wilkins, Baltimore, 353-364.

[25] Chen, T., Schulte, D.D., Koelsch, R.K. and Parkhurst, A.M. (1994) Characteristics of phototrophic and nonphototrophic lagoons for swine waste. Transactions of the American Society of Agricultural Engineers, 46, 12851292.

[26] DiMascio, P., Kaiser, S. and Sies, H. (1989) Lycopene as the most efficient biological carotenoid singlet-oxygen quencher. Archives of Biochemistry and Biophysics, 274, 532-538. doi:10.1016/0003-9861(89)90467-0

[27] Larson, R.A. (1997) Naturally occurring antioxidants. Lewis Publishers, New York, 195 p.

[28] De Leenheer, A.P. and Nelis, H.J. (1992) Profiling and quantitation of carotenoids by high-performance liquid chromatography and photodiode array detection. In: Packer, L., Ed., Carotenoids: Part A: Chemistry, Separation, Quantitation, and Antioxidation. Methods in Enzymology, Vol. 213, 251-265.

\section{doi:10.1016/0076-6879(92)13126-I}

[29] Niedzwiedzki, D.M., Sandberg, D.J., Cong, H., Sandberg, M. and Gibson, G. (2009) Ultrafast time-resolved absorption spectroscopy of geometric isomers of carotenoids. Chemical Physics, 357, 4-16. doi:10.1016/j.chemphys.2008.07.011

[30] Komori, M., Ghosh, R., Takaichi, S., Hu, Y. and Mizoguchi, T. (1998). A null lesion in the rhodopin 3,4-desaturase of rhodospirillum rubrum unmasks a cryptic branch of the carotenoid biosynthetic pathway. Biochemistry, 37, 8987-8994. doi:10.1021/bi9730947

[31] Re, R., Pellegrini, N., Proteggente, A., Pannala, A., Yang, M. and Rice-Evans, C. (1998) Antioxidant activity applying an improved ABTS radical cation decoloization assay. Free Radical Biology \& Medicine, 26, 1231-1237. doi:10.1016/S0891-5849(98)00315-3

[32] Brand-Williams, W., Cuvelier, M.E. and Berset, C. (1995) Use of free radical method to evaluate antioxidant activity. Lebensmittel-Wissenschaft und-Technologie, 28, 25-30. doi:10.1016/S0023-6438(95)80008-5

[33] Britton, G., Liaaen-Jensen, S. and Pfander, H., Eds. (1995) Carotenoids. Spectroscopy, 1B, Birkhäuser Verlag, Boston, $360 \mathrm{p}$.

[34] Amann, R.I., Ludwig, W. and Schleifer, K.-H. (1995) Phylogenetic identification and in situ detection of individual microbial cells without cultivation. Microbiology Reviews, 59, 143-169.

[35] Takaichi, S. and Shimada, K. (1992) Characterizations of carotenoids in photosynthetic bacteria. Methods in Enzymology, 213, 374-385. doi:10.1016/0076-6879(92)13139-O

[36] Takaichi, S. (1993) Usefulness of field desorption mass spectrometry in determining molecular masses of carotenoids, natural carotenoid derivatives and their chemical derivatives. Organic Mass Spectrometry, 28, 785-788. doi:10.1002/oms.1210280711

[37] Lindal, T.-R. and Liaaen-Jensen, S. (1997) Bacterial carotenoids 56 . On the spirilloxanthin stereoisomeric set. Acta Chemica Scandinavica, 51, 1128-1131. doi:10.3891/acta.chem.scand.51-1128

[38] Qian, P., Mizoguchi, T., Fujii, R. and Hara, K. (2002) Conformation analysis of carotenoids in the purple bacterium Rhodobium marinum based on NMR spectroscopy and AM1 calculation. Journal of Chemical Information and Computer Sciences, 42, 1311-1319. doi:10.1021/ci0255230

[39] Agalidis, I., Mattioli, T. and Reiss-Husson, F. (1999) Spirilloxanthin is released by detergent from Rubrivivax gelatinosus reaction center as an aggregate with unusual spectral properties. Photosynthesis Research, 62, 31-42. doi:10.1023/A:1006384113191

[40] ASAE EP403.2 (1998) Design of anaerobic lagoons for animal waste management. In: ASAE STANDARDS, ASAE, St. Joseph, MI 49085-9659.

[41] Zahn, J.A., Hatfield, J.L., Laird, D.A., Hart, T.T., Do, Y.S. and Dispirito, A.A. (2001). Functional classification of swine manure management systems based on effluent and 
gas emission characteristics. Journal of Environmental Quality, 30, 635-647. doi:10.2134/jeq2001.302635x

[42] Bergey, D.H. and Holt, J.G. (1994) Anoxygenic photo- trophic bacteria, group10: Bergey's manual of determinative microbiology. Lippincott Williams \& Wilkins, Baltimore, 353-376. 